\title{
Razumijevanje ranjivosti kao sustavnog i preciznog diskursa
}

Martina Vuk*

martina.vuk@yale.edu

https://orcid.org/0000-0001-6829-3864 https://doi.org/10.31192/np.18.3.10

UDK: 159.923 .3

159.942 .5

$27-18$

Izvorni znanstveni rad / Original sientific paper

Primljeno: 4. kolovoza 2020.

Prihvaćeno: 29. rujna 2020.

Kasnomoderna koncepcija moralnosti, kao i sam koncept ljudske osobe, dvoznačan je. S jedne strane suvremeno se poimanje osobe regulira atributima koji ističu osobnu autonomiju i distanciranost od sklonosti ranjivosti; s druge strane povećava se zanimanje za razumijevanje ranjivosti kao sve aktualnije teme. Ranjivost se pokušava razumjeti kao stanje koje čovjeka vraća njegovoj ljudskosti, odnosno sebi samom. Istodobno, u širem se kontekstu koristi kao termin za objašnjenje situacija, stanja ili koncepata koji čak i ne pripadaju poimanju ranjivosti, te se i etimološki razlikuju od samog pojma ranjivosti, poput primjerice grijeha, ljudske patnje ili stanja invalidnosti. Iako je ranjivost neizbježna, jer u čovjekov život ulazi bez njegova pristanka, suvremeni je etičko-moralni sustav s jedne strane poima kao protutežu autonomiji; a s druge strane, zbog toga što su je »iskusili« svi ljudi, često se ranjivost smatra nečim što je samo po sebi evidentno, sve dok se čovjek ne zapita što on a jest. Jer nije uvijek jasno što čovjekovo iskustvo ranjivosti uključuje ili što se razumije pod pojmom ranjivost.

Ključne riječi: autonomija, invaliditet, patnja, ranjivost, teološka antropologija.

\footnotetext{
* Dr. sc. Martina Vuk, poslijedoktorandica, Yale University, Centre For Faith \& Culture, 409 Prospect street, CT, SAD. Postdoktorski projekt financira Svicarska nacionalna zaklada za znanost.
} 


\section{Uvod}

Ranjivost kao tema rasprave i kao ljudsko iskustvo nije samo antropološka stvarnost, već etička i moralna tema. Pripada joj konceptualno i iskustveno rezimiranje: kao koncept tema je akademskih disciplina, dok joj se kao temi ljudskog iskustva pristupa unutar samog tog ljudskog iskustva. Prema tome, s obzirom na konvencionalno pa i popularno kulturološko razumijevanje, ranjivost je ili univerzalna karakteristika svih živih bića ${ }^{1}$ ili je određena kontekstom ${ }^{2}$ ili pak sustavnom kategorizacijom pojedinih skupina ljudi. Stoga što su je svi »iskusili« ili »ne iskusili«, ranjivost se često smatra nečim što je samo po sebi evidentno, sve dok je se ne pokuša definirati. Zato nije uvijek jasno što iskustvo ranjivosti uključuje ili što se razumije pod pojmom ranjivost. Istodobno, ranjivost se u širem kontekstu koristi kao terminus technicus za objašnjenje situacija, stanja ili koncepata koji čak i ne pripadaju poimanju ranjivosti, te se i etimološki razlikuju od samog pojma ranjivosti.

U kontekstu suvremene upotrebe s jedne je strane to pojam koji se nesustavno koristi ili se koristi s pogrešnom svrhom. U tom smislu možemo govoriti o instrumentalizaciji pojma ranjivosti, kao i o korištenju ranjivosti radi manipulacije. ${ }^{3}$ Npr. ranjivost se može koristiti kao izgovor za neko počinjeno moralno zlo ili bježanje od odgovornosti; ranjivost može biti i pojam suprotstavljen pojmu autonomije i moći, odnosno neranjivosti; ili je se može psihologizirati, odnosno sentimentalizirati ili pak koristiti kao termin stigmatizacije, primjerice, osoba $\mathrm{s}$ invaliditetom, psihičkih bolesnika ili socijalno ugroženih skupina. Iz svega toga proizlaze varijacije, kompleksnost, nesustavnost u samom razumijevanju pojma, koliko konceptualno, toliko još više praktično.

Svrha je ovog članka u prvom redu približiti konceptualno značenje pojma ranjivosti pridajući mu šire značenje od onog koje mu se socio-kulturološki pridaje; drugo, nakana je sustavno sagledati sam pojam ranjivosti pridajući mu precizniji i dosljedniji prikaz. U prvom dijelu se obrađuje njezino etimološko značenje, zatim kompleksnost i značenje samog pojma, razrješujući nesustavnost njegove upotrebe osvrtom na ranjivost unutar životnog iskustva, kao i koncept rasprave unutar pojedinih akademskih disciplina, ovdje posebno biomedicine, sestrinstva, etike skrbi i socijalne filozofije. U drugom dijelu se ističe

\footnotetext{
${ }^{1}$ Neki autori pridaju ranjivosti univerzalno značenje [usp. Barry HOFFMASTER, What Does Vulnerability Mean?, The Hastings Center Report, 36 (2006) 2, 38-45].

${ }^{2}$ Drugi, poput Ruth Macklin ili Marthe Nussbaum, gledaju na pojavnost ranjivosti unutar sociološko-kulturološkog konteksta. Taj socijalno-kulturološki kontekst određen je okolišem, ekonomskim čimbenicima, međuljudskim odnosima itd. [usp. Ruth MACKLIN, Bioethics, Vulnerability, and Protection, Bioethics, 17 (2003) 5-6, 472-486; vidi također Martha C. NUSSBAUM, Frontiers of Justice: disability, nationality, species, membership, Cambridge, Harvard University Press, 2006, 179-216].

${ }^{3}$ Usp. Nathalie MAILLARD, La vulnérabilité, une nouvelle catégorie morale?, Genève, Labor et Fides, 2011.
} 
kontrastna perspektiva između ranjivosti i invalidnosti te ranjivosti i pojma patnje. ${ }^{4} \mathrm{U}$ trećem i posljednjem dijelu ovog razmišljanja skreće se pozornost na ranjivost kao bitnu teološko-antropološku kategoriju te u tom pogledu posebno se ističe njezina važnost za obnovu i razumijevanje kršćanske solidarnosti.

\section{Ranjivost u suvremenom nesustavnom i kompleksnom diskursu}

\subsection{Etimološko značenje}

Pojam ranjivost dolazi od latinske riječi vulnus (u prijevodu rana), glagola vulnerare (raniti) i pridjeva vulnerabilis (ranjiv). Suvremeni rječnici na engleskom jeziku, poput Merriam Webster i Cambridge Online rječnika, ${ }^{5}$ pozivajući se na latinski korijen ove riječi, definiraju ranjivost kao sklonost slabosti, krhkosti, mogućnosti biti ranjen ili pak raniti drugoga. Francuski rječnik kršćanske etike $^{6}$ malo je bogatiji u tom pogledu razdiobe pojmova pa tako razlikuje trodimenzionalno shvaćanje ranjivosti kao pojma, manifestacije i strukture. Prema tom razumijevanju, pojam ranjivosti sastavni je dio ljudskog postojanja. Kao pojava, ranjivost se manifestira tužnim emocijama (strepnja, očaj i odbojnost) $u$ razdoblju nesigurnosti, nasilja ili smrti. Na strukturnoj razini, pojam ranjivosti često se koristi kao sinonim za krhkost, slabost i patnju, premda se razlikuje od tih pojmova zbog očite konceptualne razlike među njima.

Hrvatski pojam ranjivost ne razlikuje se previše od prethodnih značenja, ali je značenje ranjivosti pojmovno šire. U hrvatskom jeziku ranjivost podrazumijeva krhkost, nestabilnost, nesigurnost, bespomoćnost, plašljivost, nemoćnost, osjetljivost. Npr. ranjiv se većinom opisuje s fragilan, što bi značilo loman, krhak, lomljiv, osjetljiv; ${ }^{7} \mathrm{~s}$ druge strane, ranjiv može biti onaj koga je lako povrijediti ili je ranjiv u odnosu na neki subjekt ili objekt poput osobe, događaja, stanja, okruženja. ${ }^{8}$ Bez dublje semantičke analize, u hrvatskom jeziku slično se, kao i u engleskom i francuskom, ranjivost prevodi više ili manje sličnim

${ }^{4}$ Važno je istaknuti da se $\mathrm{u}$ ovom članku, zbog ograničena opsega, ne ulazi u rasprave o poimanja patnje i invaliditeta u širem sustavno-holističkom i integrativnom poimanje $u$ kontekstu personalističke bioetike.

${ }^{5}$ Usp. Merriam - Webster Dictionary, Vulnerable, https://www.merriam-webster.com/dictionary/ vulnerable (01.08.2020); vidi također u Cambridge Online Dictionary, Vulnerability, https://dictionary.cambridge.org/us/dictionary/english/vulnerability (01.08.2020).

${ }^{6}$ Maxime ALLARD, Vulnérabilite, u: Laurent LEMOINE, Eric GAZIAUX, Denis MÜLLER (ur.), Dictionnaire Encyclopédique D'Ethique Chretienne, Paris, Les Editions du Cerf, 2013, 2153-2154.

7 Usp. Hrvatska enciklopedija, Ranjiv, https://www.enciklopedija.hr/trazi.aspx?t=ranjiv (01.08.2020).

${ }^{8}$ Usp. Hrvatski jezični portal, Ranjivost, http://hjp.znanje.hr/index.php?show=search (01.08.2020). 
pojmovima ili izvedenicama za ranjivost, koja ne znači samo biti ranjiv u sebi, već i biti ranjen i otvoren ranjavanju od drugih te moći raniti druge. Iako se kao sinonim za ranjivost često koriste riječi krhkost, slabost ili sklonost patnji, ipak postoji i etimološka i konceptualna razlika između tih triju pojmova i značenja ranjivosti.

\subsection{Ranjivost i kontekst ljudskog iskustva}

Najčešći je izvor neke ranjivosti u vanjskim čimbenicima. ${ }^{9}$ To uključuje okolinu u kojoj netko živi i njegov životni prostor, socijalne ili ekonomske čimbenike, poput slabog imovinskog stanja, pothranjenosti, socijalne nepravde, loših zdravstvenih uvjeta, disfunkcionalne obitelji, kao i klimatskih i prirodnih nepogoda, poput potresa, poplava, čestih seljenja. Takvi uvjeti utječu na povećanje osobne ranjivosti kao i potrebu zaštite ranjivih pojedinaca. Uz to, suvremeni mainstream pristup ranjivosti razlikuje ranjivu sklonost $\mathrm{k}$ nečemu, primjerice, ovisnosti, bolesti, nekom načinu ponašanja, ili pak kao nesposobnost osobe da djeluje kao autonoman moralni subjekt, što je lišava donošenja odluka ili slobodnoga pristanka. ${ }^{10}$ Pristup ranjivosti i sama upotreba u kontekstu životnog iskustva također ne ovisi samo o životnom iskustvu pojedinca, već značenje ranjivosti ovisi i o kontekstu u kojem se ranjivosti pristupa ili je se doživljava. Tako se, primjerice, ranjivost pojavljuje u kontekstu zdravstva i zdravstvene etike, ljudskih prava, psihologije, popularne duhovne literature, ekologije, ekonomije ili je se pak smatra temom feminističkih rasprava, karakteristikom osoba nižeg socijalnog ili kognitivnog statusa poput, primjerice, osoba s Alzheimerovom bolešću, osoba s invaliditetom, intelektualnim teškoćama itd.

U kontekstu životnog iskustva svaka osoba može biti ona koja ranjava druge ili ona koja je ranjiva ranjivošću drugoga. U tom slučaju možemo govoriti o aktivnom i pasivnom aspektu ranjivosti, kao i o pozitivnom ili negativnom iskustvu ranjavanja. Primjerice, prepoznavanje ranjivosti u samom sebi (aktivna) i otvorenost za prihvaćanje ranjivosti druge osobe (pozitivan pristup) može biti prigoda za susret ili pak produbljenje socijalne komunikacije. ${ }^{11}$ Obrnuto, pretjerana ranjivost neke osobe na okolinu ili pak podražaje iz okoline može još više ugroziti osobni integritet te osobe ili pak povećati prirodnu ranjivost osobe, što onda ima negativne posljedice poput depresije, represije, zatvaranja za društvenu komunikaciju i socijalni angažman. Ranjivost kao pojam unutar životnog iskustva i konteksta ipak je dvosmislena, a iskustvo ranjivosti često

\footnotetext{
${ }_{9}$ Usp. Wendy ROGERS, Catriona MACKENZIE, Susan DODDS, Why bioethics needs a concept of vulnerability, International Journal of Feminist Approaches to Bioethics, 5 (2012) 2, 1138 .

${ }^{10}$ Više o odnosu ranjivosti i slobodnog pristanka vidi u [usp. Phil BIELBY, Competence and vulnerability in biomedical research, New York, Springer, 2008, 39-65].

${ }^{11}$ Usp. Martina VUK, Reconsidering Disability, Friendship and Otherness. Theological and Ethical Perspectives, doktorska disertacija, Fribourg, University of Fribourg Press, 2020, 309.
} 
proizvodi tenziju između prije spomenutog pozitivnog i negativnog poimanja, kao i aktivnog i pasivnog učinka ranjivosti. Ipak, sam pojam ranjivosti u kontekstu životnog iskustva u ovom razmišljanju podrazumijeva kompleksnost i kontroverziju, ali i traži dublju analizu. Stoga je osim prethodnog etimološkog poimanja i kratkog uvida u kontekst ljudskog iskustva, potrebno upoznati konceptualnu razradu pojma. U tom razjašnjenju od pomoći su suvremeni diskursi pojedinih akademskih disciplina.

\subsection{Sagledavanje koncepta ranjivosti iz perspektive pojedinih akademskih disciplina}

Ranjivost je tema i akademskog diskursa, do 1970. isključivo medicinskih stručnjaka, dok se od 1976. počinje koristiti u širem kontekstu, ${ }^{12}$ što uključuje i ostale akademske discipline. Ovdje se mogu izdvojiti područja biomedicine, etike skrbi i sestrinstva te izabranih područja humanističkih znanosti, poput socijalne filozofije. Zajednička karakteristika ovih disciplina, posebice područja biomedicine, etike skrbi i sestrinstva te socijalne filozofije, daje uvid u pokušaj odgovarajućeg artikuliranja koncepta ranjivosti. Primjerice, ova akademska područja razlikuju vanjski i unutarnji aspekt ranjivosti, poistovjećujući je, s jedne strane, s egzistencijalnom kategorijom svih ljudskih bića ili, s druge strane, $\mathrm{s}$ vanjskim utjecajima povećanja egzistencijalne ranjivosti. $U$ tom slučaju, osim ranjivosti kao egzistencijalne karakteristike utkane u samu narav osobe, ove discipline razlikuju ranjivost kao karakteristiku ranjivih pojedinaca i skupina kojima je potrebna odgovarajuća pravna zaštita.

U biomedicini pojam ranjivosti određuje se u odnosu na tjelesnost, biološku i fizičku funkcionalnost, odnosno nefunkcionalnost; ili krhkost nekih kognitivno-tjelesnih sposobnosti, poput samoodređenja; ili stupnja osjetljivosti na izvanjski podražaj, manipulaciju lijekovima, sklonost bolesti itd. ${ }^{13}$ Drugim riječima, pojam ranjivosti ovdje uključuje pojam ljudskog tijela i tjelesnosti, a njegovo značenje odnosi se na tjelesnu osjetljivost i fizičko stanje pacijenta. Ipak, nedavni diskurs na području biomedicine u vezi ranjivosti, reakcija je na načelo autonomije te medicinsko-tehnološku moć i kontrolu. ${ }^{14}$ To je razlog zbog kojeg se u nedavnim raspravama važnost često daje pravilnoj ocjeni odnosa pojma autonomije i ranjivosti. Znači da se ranjivost ne tumači samo u odnosu

\footnotetext{
${ }^{12}$ Usp. Henk ten HAVE, Respect for Human Vulnerability. The Emergence of a New Principle in Bioethics, Bioethical Inquiry, 17 (2015) 2, 395-408; doi: https://doi.org/10.1007/s11673-0159641-9.

${ }^{13}$ Usp. David THOMASMA, The Vulnerability of the Sick, Bioeth Forum, 16 (2000) 2, 5-12.

${ }^{14}$ Usp. Jacob D. RENDTORFF, Basic Ethical Principles in European Bioethics and Biolaw. Autonomy, Dignity, Integrity and Vulnerability. Towards a Foundation of Bioethics and Biolaw, $\mathrm{Me}-$ dicine, Health Care and Philosophy. A European Journal, 5 (2002) 3, 235-244; vidi također [usp. Soren HOLM, Not just autonomy - the principles of American biomedical ethics, Journal of medical ethics, 21 (1995) 6, 332-338].
} 
na tjelesnu funkcionalnost, već je se u nekim akademskim raspravama želi suprotstaviti pojmu autonomije. Autori, poput D. Callahana, ${ }^{15} \mathrm{M}$. Kottowa ${ }^{16}$ i J. Rendtorffa, ${ }^{17}$ razmatraju ranjivost kao temeljnu moralnu kategoriju, univerzalnu i egzistencijalnu komponentu svakog čovjeka, a ne samo pacijenta. U tom je pogledu ranjivost protuteža autonomiji, što u razumijevanju integriteta osobe može biti površno, s obzirom na to da se integritet osobe ne može svesti samo na autonomiju, niti se osobu može promatrati isključivo kroz ranjivost.

Integritet osobe zahtijeva naizmjenično vrednovanje obaju pojmova: ranjivosti i autonomije i traži posebno istraživanje. Iako i akademski smjer etike skrbi i etike sestrinstva prepoznaje ranjivost kao manifestaciju tjelesnog, za razliku od akademskog područja biomedicine u kontekstu etike skrbi i etike sestrinstva, većina argumenata naglašava odnos između koncepta ranjivosti i načela pravednosti. Važan element kod etike skrbi jest briga i odnos pružanja skrbi između pružatelja njege i primatelja, kao i životnih okolnosti primatelja njege. U kontekstu etike skrbi, odgovor na ranjivost pacijenata manifestira se kao npr. moralna odgovornost medicinskih sestara prema pacijentu. Manifestacija ranjivosti u kontekstu etike sestrinstva podrazumijeva reakciju na ranjivost pacijenta - izraženu kao potrebu pacijenta i moralnu odgovornost njegovatelja da na tu potrebu odgovori (aspekt pravednosti). ${ }^{18} \mathrm{I}$ u području etike skrbi i etike sestrinstva ranjivost se smatra aspektom životnog iskustva koji zahtijeva interpretativni dijalog između primatelja i davatelja skrbi, u ovom slučaju medicinskog osoblja i pacijenta. Ovo područje ističe međusobnu povezanost između onoga koji pruža skrb i onoga koji je prima, da bi se promicalo dostojanstvo ljudske osobe te da bi ranjivost postala normativna etička vrijednost. ${ }^{19}$

Nedavne rasprave na području humanističkih znanosti poput socijalne filozofije, socijalne politike, javnog zdravstva i feminističke filozofije pokazale su zabrinutost $u$ odnosu na pojam ranjivosti i obveze zaštite ranjivih osoba putem javnih politika. Takvi argumenti mogu se naći kod suvremenih autora, poput Marthe Nussbaum, ${ }^{20}$ Eve Feder Kittay ${ }^{21}$ i Ruth Macklin, ${ }^{22}$ kao i u djelima poli-

\footnotetext{
${ }^{15}$ Usp. Daniel CALlAHAN, Autonomy. A Moral Good not a Moral Obsession, The Hastings Center Report, 14 (1984) 5, 40-42.

${ }^{16}$ Usp. Michael H. KOTTOW, The vulnerable and the Susceptible, Bioethics, 17 (2003) 5, 460471.

${ }^{17}$ Usp. Rendtorff, Basic Ethical Principles..., 239.

${ }^{18}$ Usp. Sellman DEREK, Towards an understanding of nursing as a response to human vulnerability, Nursing Philosophy, 1 (2005) 6, 2-10.

${ }^{19}$ Usp. Chris GASTMANS, Dignity-Enhancing Care for Persons with Dementia and its Application to Advance Euthanasia Directives, u: Yvonne DENIER i dr. (ur.), Justice, Luck and Responsibililty in Health Care. Philosophical Background and ethical implications for End-of-Life care, New York, Springer, 2013, 144-145.

${ }^{20}$ Usp. Nussbaum, Frontiers of Justice..., 160-175.

${ }^{21}$ Usp. Eva F. KITTAY, Love's Labor. Essays on Women, Equality and Dependency, London, Routledge, 1999.

${ }^{22}$ Usp. Macklin, Bioethics, Vulnerability, and Protection, Bioethics..., 472-486.
} 
tičkih filozofa, poput Roberta Goodina. ${ }^{23}$ Kad se o ranjivosti govori, primjerice, u socijalnoj filozofiji, mora se reći da, iako je ranjivost dio životnog iskustva, nemaju sve osobe isti intenzitet ranjivosti. Postoje osobe koje su ranjivije i postoje osobe koje na ranjivost reagiraju drukčije. ${ }^{24}$ Prema tome, u području socijalne filozofije naglasak je na razumijevanju ranjivosti kao izvanjskom i unutarnjem čimbeniku, iskustvu okoline i pojedinca, kao i pojedinca i društva. Također, budući da ta ranjivost može biti povećana vanjskim društvenim čimbenicima i time pojačana osobna ranjivost pojedinca, razlog je to zbog kojeg socijalni filozofi inzistiraju da ranjivi subjekti trebaju odgovarajuću zaštitu. ${ }^{25}$ Odabrani autori snažan naglasak rasprave o ranjivosti stavljaju na razumijevanje odnosa ranjivosti $i$ socijalne odgovornosti, shvaćenu kao stanje pojedinca u potrebi na čiju je ranjivost potrebno uzvratiti odgovornošću. ${ }^{26}$ Također, $u$ tom kontekstu odnosa ranjivosti i odgovornosti, socijalno-pravne strukture pozvane su zaštititi ranjive pojedince kojima je zbog nepravde ugroženo dostojanstvo ili nanesena šteta. ${ }^{27}$ Osim što je ranjivost prepoznata kao egzistencijalno ljudsko stanje, socijalna filozofija se uvelike usmjerila na vanjske društvene čimbenike koji uzrokuju ranjivost, poput socijalne nepravde i isključivosti, disfunkcionalne sredine ili ekoloških nedaća koje utječu na povećanje ranjivosti osobe ili, s druge strane, neodgovarajućih socijalno društvenih čimbenika: neetičnog ponašanja, neodgovarajućih zdravstvenih uvjeta, kao i slabe ekonomske situacije, što pridonosi još većem povećanju ranjivosti pojedinca ili pojedinih društvenih skupina. ${ }^{28} \mathrm{U}$ tom smislu, ranjivost je složen odnos između prirodne sklonosti (ranjivost kao čovjekov unutarnji aspekt), ali uključuje i njegove vanjske aspekte, npr. ranjivost na koju su utjecali vanjski čimbenici.

\section{Na što se značenje ranjivosti ne odnosi ili što nije ranjivost?}

Ranjivost se kao egzistencijalnu karakteristiku živih bića, često poistovjećuje s pojmom krhkosti, patnje ili manjka autonomije. Osim tog, postoji konvencionalno usvojena tendencija da se neke skupine etiketira kao ranjive. U nastavku se opisuju dva aspekta procjene neodgovarajućeg korištenja pojma ranjivosti: ponajprije kao klasifikacije skupine, odnosno karakteristika osoba smanjenog

${ }^{23}$ Usp. Robert GOODIN, Protecting the Vulnerable. A Reanalysis of Our Social Responsibilities, Chicago, University of Chicago Press, 1985.

${ }^{24}$ Usp. Florenica LUNA, Elucidating the Concept of Vulnerability. Layers not Labels, International Journal of Feminist Approaches to Bioethics, 2 (2009) 1, 121-139.

${ }^{25}$ Usp. Samia A. HURST, Vulnerability in Research and Health Care. Describing the Elephant in the Room?, Bioethics, 4 (2008) 22, 191-202; vidi također [usp. Mary C. RUOF, Vulnerability, Vulnerable populations and Policy, Journal of the Kennedy Institute of Ethics, 14 (2004) 4, 411425].

${ }^{26}$ Usp. Goodin, Protecting the Vulnerable..., 50-83.

${ }^{27}$ Usp. Kittay, Love's Labor..., 33-55.

${ }^{28}$ Usp. Nussbaum, Frontiers of Justice..., 120-163. 
intelektualnog kapaciteta ili invalidnosti i drugo, kao pojmovne klasifikacije odveć često poistovjećivanje ranjivosti s pojmom patnje.

\subsection{Ranjivost i invalidnost}

Razumljivo je da se čovjekovu narav ne čini samo ranjivost, niti je čovjekova egzistencija svedena jedino na koncept patnje. Čovjek je složeno biće: osim što pati, on je i biće koje se raduje i nada. No, razlog zbog kojeg se ovdje ističe da se pojmu ranjivosti - kao komponenti svojstvenoj čovjeku po njegovoj biti per $s e$ - pristupa na neodgovarajući način ili da se o njoj uopće ne govori kao pojmu svojstvenu čovjekovoj biti, jest što se ranjivost često uzima kao karakteristika slabih, bolesnih, patnika; ili pak osoba s Alzheimerovom bolešću, osoba $s$ intelektualnim teškoćama, osoba niskog socijalno-ekonomskog statusa, oboljelih od side itd. Razmotrimo ovdje malo detaljnije primjer odnosa koncepta ranjivosti i invalidnosti. Belmont Report, ${ }^{29}$ primjerice, iz 1979. među prvim je međunarodnim dokumentima koji osobe klasificira na ranjive skupine. Prema tom izvješću, ranjivom se osobom smatraju oni pojedinci koji nemaju potpunu neovisnost te traže dodatnu zaštitu, poput zatvorenika, djece, osoba s intelektualnim teškoćama, trudnica, osoba s demencijom, migranata itd. Poslije su, s više ili manje odstupanja, sličnu podjelu usvojili i Council for International Organizations for Medical Sciences (CIOMS), ${ }^{30}$ kao i Ujedinjeni narodi u svojem dokumentu Respect for Human Vulnerability and Personal Integrity. ${ }^{31}$ Prema tim dokumentima, u ranjive skupine pripadaju osobe $s$ invalidnošću i intelektualnim teškoćama koje se onda, kao ranjive, dodatno klasificira i kao osobe lišene autonomije, što zaključno upućuje na to da manjak autonomije znači povećanu ranjivost. Takva podjela ili klasificiranje osoba u skupine ranjivih pojedinaca dobronamjerna je jer se ranjive skupine želi zaštititi.

Ipak, u ovom razmišljanju želi se naglasiti da terminološki, a i praktično, takvo shvaćanje ranjivosti postaje antropološki nerelevantno, s obzirom na to da osobe dijeli na ranjive i neranjive, odnosno autonomne i neautonomne. Drugim riječima, odnos između pojma ranjivosti i invalidnosti time postaje suptilan i zbunjujući. Npr. uzmemo li za primjer osobe s invalidnošću i intelektualnim teškoćama u kontekstu prethodno spomenutih dokumenata kao i

\footnotetext{
${ }^{29}$ NATIONAL COMMISSION FOR THE PROTECTION OF HUMAN SUBJECTS OF BIOMEDICAL AND BEHAVIORAL RESEARCH, The Belmont Report (18.04.1979), https: // www. hhs.gov /ohrp/regulations-and-policy/belmont-report/read-the-belmont-report/index.html (01.08.2020).

${ }^{30}$ COUNCIL FOR INTERNATIONAL ORGANIZATIONS OF MEDICAL SCIENCES (CIOMS), International Ethical Guidelines for Health-related Research Involving Humans ( $\left.{ }^{4} 2016\right)$, https://cioms.ch/wp-content/uploads/2017/01/WEB-CIOMS-EthicalGuidelines.pdf (01.08.2020).

${ }^{31}$ UNESCO, Universal declaration on bioethics and human rights (2005), https: // unesdoc.unesco.org / ark:/48223/pf0000146180 (01.08.2020).
} 
Izvještaja međunarodne zajednice bioetičkog odbora UNESCO-a o načelu poštovanja ljudske ranjivosti i osobnog integriteta (IBC) ${ }^{32}$ - zbog svoje ovisnosti o drugima, takve se osobe smatraju ranjivom skupinom i prema tome one trebaju zaštitu. U tom pogledu ranjivost je obilježje samo određene skupine osoba, a ne egzistencijalna kategorija svih živih bića (suprotno etimološkom poimanju pojma i prijašnjim razmišljanjima u kontekstu pojedinih ovdje spomenutih akademskih disciplina) te, prema tome, osobe s invalidnošću, kao skupinu ranjivih pojedinaca, treba zaštititi. Nadalje, akademske rasprave u području studija invalidnosti nisu ujednačene s obzirom na poimanje ranjivosti. Ponajprije ranjivosti se pristupa kao negativnoj karakteristici povijesno neodgovarajuće pripisanoj osobama s invalidnošću. ${ }^{33} \mathrm{U}$ tom pogledu invalidnost je ili označavala manjak autonomije, ${ }^{34}$ samoodređenosti i samostalnosti; ili pak s druge strane, invalidnost identificirana kao ranjivost, smatrala se prijetnjom društvu i autonomnim pojedincima. ${ }^{35}$

Drugo, dio znanstvenika iz područja invalidnosti smatra da je pripisivanje ranjivosti osobama s invalidnošću ili njihovo etiketiranje kao ranjivih, socijalno konstruirana karakteristika (projekcija) da bi se ranjivost prikazala kao nešto samo po sebi loše, kao prijetnja ili kao nepoželjna karakteristika postojanja. $\mathrm{U}$ tom pogledu ranjivost postaje prijetnja autonomnim subjektima, odnosno ranjivost je prijetnja autonomiji i osobe $\mathrm{s}$ invalidnošću kao ranjive s jedne se strane segregira i, s druge strane, dovodi ih se u položaj u kojem im se pridaje status niže vrijednosti.

Drugim riječima, imati intelektualnu poteškoću ili invalidnost povijesno, a u nekim društvima još i danas, znači biti nesposoban, prikraćen ili potreban pomoći i trebanja drugoga. ${ }^{36}$ Biti identificiran kao ranjiv stoga znači biti ovisan o drugima, sklon bolesti ili kategorički kvalificiran kao nesposoban i necjelovit. No stigma ranjivosti pripisana identitetu osoba s invaliditetom ne smanjuje samo pravo osobe na autonomiju, neovisnost, slobodu, već takve osobe poistovjećuje s ranjivošću. Takvo promatranje osoba primjer je razdijeljena društva na ranjive i neranjive, produljuje već ugnjetavačke konceptualne reinterpretacije i socio-kulturološka ponašanja prema osobama s invalidnošću. Takvo tumačenje upućuje na neadekvatno razumijevanje odnosa invalidnosti i ranjivosti,

${ }^{32}$ UNESCO, The Principle of Respect for Human Vulnerability and Personal Integrity: report of the International Bioethics Committee of UNESCO (IBC) (2013), https://unesdoc.unesco.org/ ark:/48223/pf0000219494 (01.08.2020).

${ }^{33} \mathrm{Npr}$. osobe s invaliditetom povijesno se stigmatiziralo kao ranjive odnosno neautonomne [usp. Margaret SHILDRICK, Becoming vulnerable. Contagious encounters and the ethics of risk, Journal of Medical Humanities, 21 (1999) 4, 215-27].

${ }^{34}$ Usp. Barbara E. GIBSON, Disability, Connectivity and Transgressing the Autonomous Body, Journal for Medical Humanities, 27 (2006) 3, 187-196.

${ }^{35}$ Usp. Deborah MARKS, Disability. Controversial debates and psychological perspectives, London, Routledge, 1999; također Shildrick, Becoming vulnerable..., 215-220.

${ }^{36}$ Usp. Simi LINTON, Claiming Disabilit. Knowledge and Identity, New York, NYU press, 1998; vidi također isti, The Disability Studies Reader, New York, Routledge, 2006. 
kao i ranjivosti i autonomije, i donosi antropološku dihotomiju, utječući na mentalni sklop mainstream društva, uzrokuje podjele na autonomne, dakle, neranjive, i neautonomne, odnosno ranjive osobe.

Strah od priznavanja vlastite ranjivosti autonomnih pojedinaca, ili pak etiketiranje neke skupine pojedinaca ranjivima, služi potiskivanju ili bježanju pred priznavanjem vlastite ranjivosti; drugim riječima, stvara strah od gubitka autonomije. Da bi se takva dihotomija izbjegla, predlaže se, da se umjesto selektivne podjele na ranjive i neranjive pojedince, ili s obzirom na osobe s invalidnošću ili bez nje, u antropološke koncepcije ranjivosti kao egzistencijalne kategorije svih živih bića uvrsti podjela s obzirom na stupanj ranjivosti - što bi, uz priznavanje ranjivosti kao univerzalne egzistencijalne osobine živih bića, značilo podjelu na osobe s manjim ili većim stupnjem ranjivosti. Imajući na umu poštivanje integriteta osobe, svakoj je osobi metafizički i ontološki darovan identitet dostojanstva, ${ }^{37}$ a to bi onda $u$ kontekstu ove rasprave značilo da i osoba s invalidnošću, uz povećanu ranjivosti, zaslužuje poštovanje, kao što ga zaslužuje i svaka autonomna i istodobno (egzistencijalno i ontološki) ranjiva osoba. Drugim riječima, takvo poimanje onda znači odmak od selektivne podjele osoba na ranjive i na autonomne. Umjesto toga poziva se na vrijednost osobe kao dostojansvene i cjelovite, gdje autonomija i ranjivost nisu protutežni ili isključivi pojmovi, već korelativni i integrativni. ${ }^{38}$

\subsection{Ranjivost svedena na patnju}

Već je spomenuta karakteristika ranjivosti u kojoj se ona svodi na pojam patnje ili se poistovjećuje s njom. Korijen takvog razmišljanja jest poistovjećivanje pojma ranjivosti s patnjom, kao i, s druge strane, neodgovarajućim poimanjem patnje kao negativne egzistencijalne kategorije..$^{39}$ Iako je problematiziranje pat-

\footnotetext{
${ }^{37}$ Usp. HRVATSKA BISKUPSKA KONFERENCIJA (za uporabu korištenja na hrvatskom jeziku), Katekizam Katoličke crkve, u br. 1934-1936; br. 1939; br. 1944-1945, Zagreb, Glas Koncila, 1994; Michele ARAMINI, Uvod u bioetiku, Zagreb, Kršćanska sadašnjost, 2009, 81; Karol WOJTYŁA, Osoba $i$ čin, Split, Verbum, 2017.

${ }^{38}$ Iako se temi suodnosa autonomije i ranjivosti, kao i invalidnosti i ranjivosti, ne može ovdje pristupiti iz svih aspekata i poimanja, budući da se ranjivost promatra kao egzistencijalnu kategoriju svih živih bića, a istodobno pojedine osobe kao ranjivije ili neranjive, odnosno neautonomne, predlaže se sustavnija elaboracija ovog suodnosa pozivajući se na, primjerice: PARTNERS IN THE BIOMED II PROJECT, The Barcelona declaration on Policy proposals to the European Commission on Basic ethical principles in Bioethics and Biolaw (November, 1998), https://web.archive.org/web/20000817095021/ http://www.ruhr-uni-bochum.de:80/zme/Barcelona.htm (01.08.2020); [vidi također Peter KEMP, Jacob RENDTORFF, The Barcelona Declaration, Synthesis philosophica, 23 (2008) 2, 239-251; Ivana ZAGORAC, What vulnerability? Whose vulnerability? Conflict of understandings in the debate on vulnerability, Journal of Health Care for the Poor and Underserved, 27 (2016) 4, 1655-1671; Paul RICOEUR, Oneself as Another, Chicago, The University of Chicago Press, 1992].

${ }^{39}$ Usp. Jeffrey TRANZILLO, John Paul II on the Vulnerable, Washington, Catholic University of America Press, 2013. U ovog autora, uz vrijedan doprinos razumijevanju socijalnih enciklika
} 
nje kao konceptualne i pragmatične kategorije široko i izvan ovoga razmišljanja, važno je ipak naglasiti da, iako suptilna, razlika između pojma patnje i ranjivosti ipak postoji, što upućuje na preciznije pojmovno razlikovanje. Naime, osim što ranjivost podrazumijeva ontološku dimenziju ljudske egzistencije, patnja se kao egzistencijalna mogućnost ne može ontologizirati. ${ }^{40}$ Patnja prema nekom konvencionalnom značenju većine suvremenih (online) rječnika, odnosi se na stanje tjelesne ili mentalne boli, agonije i borbe sa smrću, ${ }^{41}$ no kao egzistencijalna zadanost nije trajna, ili pak joj je svrha spasonosni, blagoslovni i otkupiteljski učinak na čovjeka. ${ }^{42}$ Patimo, primjerice, samo u nekim trenutcima života, $\mathrm{u}$ nekim okolnostima ili zbog stanovitih okolnosti, ljudi ili zbog nepravde.

Iako se kategorički, ranjivost kao ontološku zadanost ne može ukloniti jer upućuje na čovjekovu sklonost prema vrsti patnje, kao kriterij razlikovanja tih dvaju stanja ljudske egzistencije od pomoći mogu biti tipovi i manifestacije ranjivosti. Ranjivost kao ontološka kategorija ljudskog bića prepoznaje se na tjelesnom, duhovnom ili socijalnom području ljudskog života ili stanja. U tom kontekstu ona se može prepoznati kao bol, kao patnja ili nemoć, ovisno o stupnju njezina intenziteta kao i sposobnosti ili nesposobnosti osobe da na ranjivost reagira na drukčiji i sebi svojstven način. Tad se može govoriti o tjelesnoj, socijalnoj ili psihološkoj manifestaciji ranjivosti ${ }^{43}$ koja se može reflektirati kao tjelesna, psihološka i socijalna patnja. ${ }^{44}$ Upravo manifestacija ranjivosti pokazuje konceptualnu, iako suptilnu, razliku između stanja patnje i stanja ranjivosti.

Radi boljeg razumijevanja odnosa ranjivosti i patnje važno je usmjeriti se na manifestacije ranjivosti kao kriterij razlikovanja. Tako, primjerice, tjelesna manifestacija ranjivosti uključuje tjelesni aspekt, odnosno tjelesnu fizionomiju kao biološku tjelesnu zadanost, što uključuje tjelesnu krhkost, sklonost bolesti ili tjelesnu slabost. Manifestacija ranjivosti na razini tijela intenzivnija je u prvih nekoliko mjeseci ljudskog života i kod procesa starenja. Psihološka manifestacija ranjivosti tipično podrazumijeva izljev emocija ili povredu i patnju na emocionalno-psihološkoj razini. Socijalno-odnosna ili samo odnosna (relacijska) manifestacija, uz tjelesnu, jedna je od najraširenijih manifestacija

Ivana Pavla II., može se uočiti neadekvatno asociranje patnje s ranjivošću i obrnuto.

${ }^{40}$ Slična i šira razmišljanja mogu se uočiti u sljedećim djelima: Karen KILBY, Rachel DAVIES (ur.), Suffering and the Christian Life, London, T\&T Clark, 2020; Eric J. CASSEL, The Nature of Suffering and the Goals of Medicine, New York, Oxford University Press, 1991; Stanley HAUERWAS, Suffering Presence. Theological Reflections on Medicine, the Mentally Handicapped and the Church, Illinois, University of Notre Dame Press, 1986.

${ }^{41}$ Usp. Hrvatska enciklopedija, Patnja, https://www.enciklopedija.hr/trazi.aspx?t=patnja (01.08.2020); Cambridge Online Dictionary, Suffering, https://dictionary.cambridge.org/dictionary/english/suffering, (01.08.2020); Centre National de Ressources Textuelles et Lexicales, Souffrance, https://www.cnrtl.fr/definition/Souffrance (01.08.2020).

${ }^{42}$ Usp. Jacques GUILLET, Patnja, u: Xavier Leon-Dufour (ur.), Rječnik biblijske teologije, Zagreb, Kršćanska sadašnjost, 1993, 840-847.

${ }^{43}$ Ova podjela preuzeta je u usporedbi s podjelom u Maillard, La vulnérabilité..., 196-199.

${ }^{44}$ Usp. IVAN PAVAO II., Apostolsko pismo Salvifici Doloris - Spasonosno trpljenje (11. veljače 1984.), Zagreb, Kršćanska sadašnjost, 2003. 
ranjivosti s obzirom na to da uključuje bližu ili dalju svakodnevnu komunikaciju s ljudima, prijateljima, partnerom, kolegama, bolničkim osobljem itd. To znači da kao pojedinci nismo ranjeni samo potrebom za drugima, već i sama ta potreba za drugim izaziva rizik s kojim ulazimo ili ne ulazimo u odnos s drugom osobom. ${ }^{45}$ Ono što takva podjela ranjivosti uključuje jest da ranjivost koja se manifestira na nekom području tjelesnosti, socijalnog konteksta ili životnih okolnosti sama po sebi jest trajnost, dok se manifestacija ranjivosti na nekom području prepoznaje kao patnja, a njezin urok je ranjivost. Iako i ranjivost i patnja u suvremenom čovjeku izaziva i strah i potrebu da ih se ukloni, potrebno je istaknuti da, paradoksalno, ranjivost koju se nastoji potisnuti da bi se uklonila patnja, rezultira time da se uklanjanjem patnje zapravo povećava ranjivost. ${ }^{46}$

$\mathrm{U}$ tom pogledu područje kršćanske solidarnosti, teološke antropologije i personalističke bioetike, teoretski i praktično, svojevrsna su lokacija daljnjih rasprava ovakvih i sličnih razmišljanja o ranjivosti.

\section{Ranjivost $i$ kršćanska solidarnost u službi promicanja inkluzije}

U teološko-antropološkoj i socijalno-etičkoj perspektivi ranjivost se definira kao ontološko stanje čovjeka iz kojeg onda proizlazi i socijalno-odnosni aspekt ili manifestacija ranjivosti. Drugim riječima, ranjivost, kao teološko-antropološka zadanost, ukazuje na čovjekovu potrebu za drugim ljudskim bićem, a time i za solidarnošću u smislu da čovjek kao ljudsko biće nije samo ranjiv unutar svoje ontološke prirode, već je ranjiv samom potrebom trebanja drugoga. ${ }^{47}$

Katekizam Katoličke crkve (KKC, brr. 1934-1939), ukazujući na društveno-socijalnu dimenziju čovjekova zemaljskoga života, ističe pitanje socijalne jednakosti radi postizanja socijalne pravednosti. Poveznica KKC, br. 1934. i br. 1936., upućuje na ono što će se ovdje istaknuti kao socijalno-odnosni aspekt ljudske ranjivosti u perspektivi trebanja drugoga. KKC, ukazujući na jednako dostojanstvo i jedinstvenost čovjekove prirode i podrijetla u br. 1934. i br. 1936. naglašava potrebu za drugim. Nadalje, u pogledu važnosti poštovanja unutarnjeg dostojanstva ljudske osobe, KKC u br. 1944., ukazuje na poštovanje drugog u relaciji razumijevanja sebstva. Poštovanje drugoga kao drugog ovdje, posebno u vezi s br. 1939.. upućuje na odnos s drugim te se time doživljava i kao mjesto za solidarnost. U tom pogledu ranjivost je poziv i mogućnost za susret s drugim, gdje se drugoga gleda na razini simetrije (dakle sličnosti), a ne različitosti koja antropološki razdvaja ljude na ranjive i neranjive.

\footnotetext{
${ }^{45}$ Usp. Vuk, Reconsidering Disability..., 315.

${ }^{46}$ Martina VUK, Vulnerability and Flourishing in Time of COVID-19 (07.07.2020), https://ypa. yale.edu/postdoc-symposium/program (01.08.2020).

${ }^{47}$ Usp. Vuk, Reconsidering Disability..., 315-318.
} 
Budući da nisu samo ranjivi oni koji trebaju autonomne pojedince, već su egzistencijalno i autonomni pojedinci oni koji ovise o osobama s većim stupnjem ranjivosti (relacijsko-recipročan odnos autonomije i ranjivosti). Takvo poimanje ranjivosti kao egzistencijalne i sociološko-odnosne komponente ne potiče samo solidarnost i socijalnu pravednost, već i utječe na ispravnije razumijevanje dinamike suživota i međusobne pripadnosti. Povezano s time, ranjivost kao društveno-etička komponenta u tom pogledu, aspektom brige za drugoga upućuje na transformaciju kršćanske solidarnosti. No, u čemu se konkretno takva solidarnost očituje? Naime, na temelju dosadašnjeg diskursa moglo se vidjeti da nijekanje ranjivosti kao egzistencijalne kategorije ukazuje na kulturološko-sociološko odbijanje čovjekove egzistencijalne ograničenosti i tjelesne krhkosti.

Drugim riječima, poricanje ranjivosti kao nečega što pripada čovjeku po njegovoj biti per se i, s druge strane, etiketiranje samo određene skupine pojedinaca ranjivima, na široj društvenoj razini izaziva otklon, strah i nelagodu prema, s jedne strane, egzistencijalnoj komponenti ranjivosti i, s druge strane, prema onima koje je sustav etiketirao kao ranjive. Takav stav, nadalje, uzrokuje socijalnu, ekonomsku i kulturološku podjelu između moćnih i nemoćnih, sposobnih i nesposobnih, ranjivih i neranjivih. Poricanje ranjivosti kao egzistencijalne kategorije, a time i antropološke, ponajviše pogađa osobe s većim stupnjem ranjivosti, no pritom istodobno rasvjetljuje uokvirenost društvenog, etičkog i pravnog aparata. Ponekad marginalizacija ili odbacivanje pojedinca nije uzrokovano ekonomsko-pravnim odbacivanjem ranjive ljudskosti, već se odražava kao socijalna nepravda ili odbacivanje pojedinca kao drukčijega, zbog čega nastaje izolacija, marginalizacija, usamljenost i socijalno-odnosna osamljenost. Drugim riječima, takav sustav vrijednosti, koji odbacuje ili marginalizira ranjivost, stvara opasan socijalno-vrijednosni sustav temeljen na neranjivosti i tehnokraciji.

Ovdje je važno naglasiti da antropološka dihotomija između abnormalnog i normalnog, slabih i jakih, bogatih i siromašnih nije samo etički i moralno problematična, već je to poziv na obnovu šireg društvenog konteksta, posebno u kontekstu socijalne inkluzije i solidarnosti. Prema tome je ključan aspekt ranjivosti, kao društveno-etičke dimenzije, poziv na obnovu solidarnosti kao odnosne kategorije, umjesto da je se svodi na kriterij raspodjele prava i sloboda. Tu može pomoći razmišljanje Ivana Pavla II.$^{48}$ prema kojem solidarnost uključuje međuovisnost, što ponajprije znači, ne uzimati drugoga kao instrument ili kao suparnika, već kao pomoćnika, suputnika ili onoga koji je u potrebi i treba moju pomoć.

Važnost ranjivosti za obnovu solidarnosti i socijalne inkluzije je u tome što ona suprotstavlja i osvjetljuje prevladavajući sustav etičkog razmišljanja teme-

\footnotetext{
${ }^{48}$ IVAN PAVAO II., Evangelium vitae. Evandelje života - Enciklika o vrijednosti i nepovredivosti ljudskog života (25. ožujka 1995.), Zagreb, Kršćanska sadašnjost, 1997.
} 
ljenog na etici jačega i autonomije. A takav sustav ranjivost kao kategoriju i ranjive pojedince kao skupinu, ne svrstava samo na margine društvene participacije, već ljudsko dostojanstvo reducira na isključivo materijalnu vrednotu, a ranjivosti pripisuje negativno značenje. No, biti svjestan ljudskosti pojedinca i drugoga više je od svođenja sebe i drugoga na subjekt moralne odgovornosti jer se temelji na načelu dara i darivanja. Ili, drugačije rečeno, drugi je darovan meni kao osoba (ranjiva i autonomna $u$ isto vrijeme) i ja sam darovan drugoj osobi kao drugi. Time je solidarnost temeljena na pravu i dužnosti izazvana solidarnošću ljudske participacije. S teološkog stajališta, stigmatizacija ili diskriminacija ranjivosti ili marginalizacija osoba s izraženijom ranjivošću, zapravo je protu-inkluzivna, ponajprije stoga što marginalizacija takvih osoba ne uzrokuje samo izolaciju, već ju se neizravno dovodi u rizik zaborava ljudskosti svodeći ga na pasivnost jer se ranjive osobe odmiče od pune aktivne participacije u društvu i Crkvi.

Prema tome, potrebno je istaknuti, da iskustvo ranjivosti, ili sve veća osjetljivost za ranjivost, kao univerzalne komponente pripisane čovjekovoj biti, može biti inspiracija i orijentacija socijalne etike prema solidarnosti participacije (kroz primjerice susret ili prijateljstvo sa migrantima, osobama različitog socijalnog statusa, osobama sa mentalnim i psihosocijalnim poremećajima, osobama sa invaliditetom itd.). To znači da je, kada se ranjivost uzima kao egzistencijalna i socijalno-etička kategorija, solidarnost je koncipirana kao put k inkluziji i obrnuto. Stoga je potreba solidarnosti participacije ključna i vitalna kategorija za etiku ranjivosti da bi se ranjive osobe ili osobe s izraženijim stupnjem ranjivosti ponovno humaniziralo i uključilo u antropološki sustav društva kao nestigmatizirane i nediskriminirane.

\section{Zaključak}

Nakana ovog članka bila je skretanje pozornost na važnost ranjivosti kao konceptualne, ali i životne kategorije, kao i na neadekvatnost i nerelevantnost diskursa u pogledu upotrebe samog pojma ranjivosti. I konceptualno i kontekstualno, rasprave o ranjivosti i dalje su prilično podijeljene između onih koji je smatraju pozitivnom i onih koji ranjivost vide kao negativno stanje ili kao prijetnju. Stoga se značenje ranjivosti ne uspijeva jednoglasno internalizirati kao pozitivna ili negativna konotacija, ili pak univerzalna ili parcijalna kategorija, zbog čega se podjela mišljenja u odnosu na pojam ranjivosti i dalje nastavlja. Unatoč nedosljednosti konceptualnih sporazuma u odnosu na pojam ranjivosti u domeni akademskih disciplina, još uvijek postoji očigledan suvremeni »poticaj« (osobito u sadašnjoj situaciji pandemije virusa Covid-19) izražen u ljudskoj potrebi za prepoznavanjem ranjivosti kao životne stvarnosti. Stoga, ranjivost, osim što se smatra jedinstvenim i složenim stanjem, nije samo 
univerzalna prirodna sposobnost da se bude ranjen ili sklon raniti druge, već složen i kontroverzan pojam koji traži dublju analizu, ali istodobno ne sprječava osobu da ostvari svoje mogućnosti rasta i napretka. Ranjivost kao bitna teološka kategorija, služi obnovi kršćanske solidarnosti s ciljem promoviranja personalističke etike participacije i skrbi za drugoga. U tom kontekstu suočavanje sa ranjivošću može proširiti vidik kršćanske solidarnosti u smislu da postane više participirajuća, a manje deontološka te da međusobna pripadnost kao element kršćanske solidarnosti bude određena dinamikom prihvaćanja različitosti, umjesto pretjeranog isticanja antropološkog utilitarizma koje suvremeni globalno-pluralistički kontekst nameće. 


\section{Martina Vuk* \\ Understanding Vulnerability - Towards a Systematic and Concise Discourse}

Summary

The modern conception of morality, as well as, the concept of human person is twofold. On the one hand it is regulated by attributes that emphasizes personal autonomy regardless of human vulnerability; on the other hand, there is a growing interest towards understanding the notion of vulnerability as a contextual and conceptual issue. Vulnerability is tried to be understood as a state that returns a person to his humanity, that is, to himself. At the same time, in a broader context, it is used as a term to explain situations, conditions or concepts that do not even belong to the domain of vulnerability, and are etymologically different from the concept of vulnerability, such as sin, human suffering or disability. Despite all the efforts of the contemporary culture to eliminate it, vulnerability not merely counterbalances the notion of autonomy, but as an inevitable existential category enters our lives without our consent. Because everyone has »experienced« it, vulnerability is considered as a selfevident phenomenon until we are asked to define it. For this reason, it is not always clear what the experience of vulnerability involves or what we mean by the notion vulnerability.

Key words: autonomy, disability, suffering, theological anthropology, vulnerability.

(na engl. prev. Martina Vuk)

\footnotetext{
* Martina Vuk, PhD, STD; Postdoctoral Scholar, Yale University, Centre for Faith and Culture; Address: 409 Prospect Street, CT, USA; E-mail: martina.vuk@yale.edu.
} 